\title{
Effect of Gibberellic Acid Alone or Combined with Two Antioxidants on Fruit Set, Yield and Fruit Quality of "Hollywood" and "Golden Japanese" Plum Cultivars
}

\author{
W.A. Nabil, Magda, N. and A. S. Wally \\ Horticulture Research Institute, Agricultural Research Centre, \\ Cairo, Egypt.
}

HE PRESENT investigation was conducted during two
successive seasons of 2011 and 2012 on "Hollywood" and
"Golden Japanese" plum trees (Prunus salicina). The trees were 15
years old and grown in private orchard at Menofia governorate.
Gibberellic acid at 25 and 50 ppm alone or combined with citric or
ascorbic acid at $50 \mathrm{ppm}$ were sprayed twice (at full bloom and 2
weeks later) on both plum cultivars.

All treatments increased fruit set (\%) and fruit yield (Kg/tree) and improved fruit quality of the two cultivars in the two studied seasons. The most effective treatment on fruit yield increment and fruit quality improvement was spraying gibberellic acid at $50 \mathrm{ppm}$ combined with citric or ascorbic acid at $50 \mathrm{ppm}$ (at full bloom and 2 weeks later).

Keywords: Plum, Hollywood, Golden Japanese, Yield and Fruit set.

Plums (prunus salicina) are occupying an important tree share in the total fruit production of Egypt. The total area of plums in Egypt reached about 2645 Feddans, according to the census of the Ministry of Agriculture. Egypt produced 7376 tons of plum fruits with an average yield of 2.99 tons / Fed. (Ministry of Agriculture, 2010).

Gibberellic acid (GA) has an important role in fruit set. There are three important actions (mode of action) for GA. The first is that GA intensifies an organ ability to function as a nutrient sink. The second action is the ability of GA to increase the synthesis of IAA in plant tissues. The third one involves accelerating synthesis of hydrolytic enzymes as amylase in the aleurone layer of seeds (Addicott \& Addicott, 1982).

In order to increase persimmon fruit set and reduce fruit abscission, trees were treated with various growth regulators. A spray of gibberellic acid at a concentration of 15-30 ppm at full bloom significantly increased yield (by 50$400 \%$ ). In young persimmon trees (4-5 years old), a narrow (2-3 mm) girdling at the time of sprouting, together with $\mathrm{GA}_{3}$, gave best results (Blumenfeld, 1981). It has been found that mixing $\mathrm{GA}_{3}$ with foliar fertilizer (N, P, K, Mn, Fe and Zn) increased the yield of "Valencia" orange trees (Soliman, et al., 1985). It had been reported that the combination of $\mathrm{GA}_{3}$ and $\mathrm{AVG}$ (aminoethoxylevinylglycine) delay fruit maturation, increase fruit size and improve storage life of 'Feicheng' 
peaches (Zhiguo et al., 1999). Abd El-Mageed, et al. (2007) on "Canino" apricot and Chitu et al. (2007) on pear found that the highest fruit set, yield and fruit quality were obtained by spraying $\mathrm{GA}_{3}$ at $20 \mathrm{ppm}$ at full bloom as compared with untreated trees (the control). Moreover, sweet cherry (Prunus avium) trees treated with the optimum concentration of $\mathrm{GA}_{3}(25 \mathrm{ppm})$ in two different locations yielded fruits with $13.4 \%$ and $14.1 \%$ greater weight and $38 \%$ and $25 \%$ higher firmness compared to control (Canli and Orhan, 2009).

Ascorbic acid and citric acid are two natural and organic antioxidants have auxinic action, they provided disease control against most fungi infections on different fruit trees (Elad, 1992). These compounds had synergistic effect on improving growth and productivity of "Flame Seedless" grapes (Farag, 1996). Ascorbic and citric acids spraying at 200,300 and 400 ppm and active dry yeast at $3 \mathrm{~g} / \mathrm{L}$ increased yield as $\mathrm{kg} /$ tree, fruit weight, pulp firmness, total soluble solids (TSS ), ascorbic acid, starch (\%), reducing sugars, non-reducing sugars, total sugars and total phenols of "Alphonse" and "Badami" mango fruits (Awad, 2006). Ascorbic acid is a highly abundant metabolite and has an important role in plant stress physiology. It is a key antioxidant, enzyme co-factor and precursor for oxalate and tartarate as well as plays a role in photo-protection, wounding response, insect herbivory and cell expansion (Conklin, 2001). Moreover, "Anna" apple fruit physical and chemical characteristics were improved by spraying citric acid at $0.1 \%$ at three times: at growth start, just after fruit set and at 21 days later (Ahmed and Abd El-All, 2007). Moreover, Mohamed (2008) found that spraying "Kelsey" plum trees by some antioxidants (Tryptophan, ascorbic acid and vitamin E) increased yield and improved fruit quality as compared with the untreated trees. Recently, Wally, et al. (2012) found that spraying $\mathrm{GA}_{3}$ plus two antioxidants (citric and ascorbic acids) increased "Canino" apricot crop and improved fruit quality. Also, applied antioxidants (ascorbic acid at $250 \mathrm{mg} / \mathrm{l}$, salicylic acid at $250 \mathrm{mg} / \mathrm{l}$, seaweed extract acid at $1000 \mathrm{mg} / \mathrm{l}$ and yeast extract at $1000 \mathrm{mg} / \mathrm{l}$ ) by (pre-soaked or foliar spray) on soybean plant increased seed yield of plants grown under salinity stress compared with the control (Sakr et al., 2013).

The aim of the present investigation was to study the effect of spraying gibberellic acid alone or combined with two antioxidants namely citric and ascorbic acids at different concentrations on fruit set, yield and fruit quality of "Hollywood" and "Golden Japanese" plum (Prunus salicina) cultivars during two successive seasons of 2011 and 2012

\section{Materials and Methods}

The present investigation was conducted during the two successive seasons of 2011 and 2012 on "Hollywood" and "Golden Japanese" plum (Prunus salicina) cultivars grown at a private orchard in El-Monofia governorate. The selected trees were 15-years old, almost uniform in vigor, grafted on Mariana rootstock and planted at $6 \times 6 \mathrm{~m}$ apart. Twenty one trees were chosen for each cultivar for

Egypt. J. Hort. Vol. 40, No.1 (2013) 
carrying out 7 treatments in this study, each treatment was replicated three times (one tree for each replicate) according to a Randomized Complete Block Design. Gibberellic acid, citric acid and ascorbic acid were sprayed twice (at full bloom and 2 weeks later) and the treatments were arranged as follows:

- Control (sprayed with tap water).

- $\mathrm{GA}_{3}$ spraying at $25 \mathrm{ppm}$.

- $\mathrm{GA}_{3}$ spraying at $50 \mathrm{ppm}$.

- Citric acid at 50 ppm.

- Ascorbic acid (vitamin C) at 50 ppm.

- $\mathrm{GA}_{3}$ spraying at $50 \mathrm{ppm}$. + Citric acid at $50 \mathrm{ppm}$.

- $\mathrm{GA}_{3}$ spraying at $50 \mathrm{ppm}$. + Ascorbic acid (vitamin C) at $50 \mathrm{ppm}$.

All the sprayed substances were sprayed until run off $(5 \mathrm{~L} /$ tree $)$.

During the two study seasons, four branches representing all tree sides were chosen at random and labeled before spraying. Fruit set (\%) was measured by calculated the number of set fruits/100 flowers.

At picking date, average number of fruits/tree was counted and fruit yield (Kg/tree) was calculated by multiply number of fruits/tree $\mathrm{x}$ the average of fruit weight. Samples of twenty fruits from each replicate were taken to determine the following characteristics:

- Average fruit weight (gm).

- Average fruit volume $\left(\mathrm{cm}^{3}\right)$.

- Average fruit dimensions (length and diameter $\mathrm{cm}$ ).

- Average fruit firmness $\left(\mathrm{lb} / \mathrm{inch}^{2}\right)$ was estimated by Magness and Taylor (1925) pressure tester.

- Total soluble solids (\%) of fruit juice was estimated by using hand refractometer.

- Total acidity (\%) was calculated as $\mathrm{mg}$ malic acid/100g fresh weight (A.O.C.A., 1990).

- TSS/acid ratio was determined.

Statistical analysis:

All obtained data were statistically analyzed according to Steel and Torrie (1980). New L.S.D. at 5\% test was used for comparison between means of the studied treatments.

\section{Results and Discussion}

Fruit set

Results in Table 1 show the effects of gibberellic acid at 25 and 50 ppm alone or combined with citric and ascorbic acids at $50 \mathrm{ppm}$ on fruit set (\%) of "Hollywood" and "Golden Japanese" plum. All sprayed treatments increased significantly fruit set $(\%)$ as compared with the unsprayed treatment (control). The highest fruit set values (25.8 and 24.8\%) for "Hollywood" and (32.5 and $43.88 \%$ ) for "Golden Japanese" were recorded by the treatment of spraying 
gibberellic acid at $50 \mathrm{ppm}$ combined with citric acid at $50 \mathrm{ppm}$ as compared with the lowest values (17.29 and 16.9\%) for "Hollywood" and (26.58 and 25.52\%) for "Golden Japanese" which resulted from the control treatment, in the first and second seasons, respectively. The other treatments recorded in between fruit set values.

The current results agree with those obtained by Blumenfeld (1981) and El-Sheikh et al. (1999) using gibberellic acid at 15-30 ppm at full bloom on persimmon; and those reported by Abd El-Megeed et al. (2007) and Chitiu et al. (2007) who used $\mathrm{GA}_{3}$ and boron on "Canino" apricot and pear and with those indicated by Canli and Orhan, (2009) applying gibberellic acid on sweet cherry. As for antioxidants effects, the present results are in line with the results of Farag (1996) on grapevine, the results revealed on "Anna" apple by spraying citric acid at $0.1 \%$ at three times: at growth start, just after fruit set and at 21 days later (Ahmed and Abd El-All, 2007) and the previous results of Mohamed (2008) who found that spraying "Kelsey" plum trees by some antioxidants (Tryptophan, ascorbic acid and vitamin E) increased yield and improved fruit quality as compared with the untreated trees. Also, the present results are in harmony with those of Wally et al. (2012) who studied the effect of gibberellic acid and two antioxidants (citric and ascorbic acids) on yield and fruit quality of "Canino" apricot trees.

TABLE 1. Effect of spraying $\mathrm{GA}_{3}$ alone or combined with two antioxidants on fruit set $(\%)$ for plum fruits during 2011 and 2012 seasons.

\begin{tabular}{|c|c|c|c|c|}
\hline \multirow{3}{*}{ Treatments } & \multicolumn{4}{|c|}{ Fruit set (\%) } \\
\hline & \multicolumn{2}{|c|}{ Hollywood } & \multicolumn{2}{|c|}{ Golden Japanese } \\
\hline & 2011 & 2012 & 2011 & 2012 \\
\hline Control & $17.29 \mathrm{c}^{*}$ & $16.90 \mathrm{c}$ & $26.58 \mathrm{c}$ & $25.52 \mathrm{c}$ \\
\hline $\mathrm{GA}_{3}$ at $25 \mathrm{ppm}$ & $21.23 \mathrm{~b}$ & $20.10 \mathrm{~b}$ & $28.27 \mathrm{~b}$ & $39.36 \mathrm{~b}$ \\
\hline $\mathrm{GA}_{3}$ at $50 \mathrm{ppm}$ & $22.11 \mathrm{~b}$ & $21.25 \mathrm{~b}$ & $29.10 \mathrm{~b}$ & $39.56 \mathrm{~b}$ \\
\hline Citric acid at $50 \mathrm{ppm}$ & $22.15 \mathrm{~b}$ & $21.70 \mathrm{~b}$ & $29.90 \mathrm{~b}$ & $41.20 \mathrm{~b}$ \\
\hline Vitamin C (ascorbic acid) at $50 \mathrm{ppm}$ & $22.78 \mathrm{~b}$ & $22.75 \mathrm{~b}$ & $29.5 \mathrm{~b}$ & $40.90 \mathrm{~b}$ \\
\hline $\mathrm{GA}_{3}$ at $50 \mathrm{ppm}+$ Citric acid at $50 \mathrm{ppm}$ & $25.80 \mathrm{a}$ & $24.80 \mathrm{a}$ & $32.5 \mathrm{a}$ & $43.88 \mathrm{a}$ \\
\hline $\mathrm{GA}_{3}$ at $50 \mathrm{ppm}+\mathrm{Vitamin} \mathrm{C}$ at $50 \mathrm{ppm}$ & $23.93 \mathrm{a}$ & $24.10 \mathrm{a}$ & $31.9 \mathrm{a}$ & $42.36 \mathrm{a}$ \\
\hline
\end{tabular}

*Values having the same letter(s) within the same column are not statistically significant using new L.S.D. at $5 \%$.

\section{Fruit yield}

Results in Table 2 indicate the effect of gibberellic acid at 25 and $50 \mathrm{ppm}$ alone or combined with citric and ascorbic acids at $50 \mathrm{ppm}$ on fruit number/tree and yield (Kg/tree) of "Hollywood" and "Golden Japanese" plum cultivars. The fruit number/tree was different from season to season and from cultivar to another and that reflect to fruit weight. The high number of fruits results from small fruits. The good indicator of the yield was the yield weight ( $\mathrm{Kg} / \mathrm{per}$ tree).

Egypt. J. Hort. Vol. 40, No.1 (2013) 
All sprayed treatments increased significantly yield ( $\mathrm{Kg} /$ tree) as compared with the unsprayed treatment (control). As regard to "Hollywood" cultivar, the highest yield $(\mathrm{Kg} /$ tree $)$ value $(19.96 \mathrm{Kg} /$ tree $)$ in the first season was recorded by the treatments of spraying gibberellic acid at $50 \mathrm{ppm}$ combined with citric acid at 50 ppm and $(24.18 \mathrm{Kg} / \mathrm{tree})$ in the second season was recorded by the treatment of gibberellic acid alone at $50 \mathrm{ppm}$ as compared with the lowest values (13.87 and $16.00 \mathrm{Kg} /$ tree) which resulted from the control treatment, in both first and second seasons, respectively. The other treatments recorded in between yield $(\mathrm{Kg} / \mathrm{tree})$ values. As regard to "Golden Japanese" cultivar, the highest yield ( $\mathrm{Kg} / \mathrm{tree})$ values $(39.63$ and $25.46 \mathrm{Kg} /$ tree) were recorded by the treatment of gibberellic acid at $50 \mathrm{ppm}$ combined with ascorbic acid at $50 \mathrm{ppm}$ as compared with the lowest values $(25.70$ and $19.41 \mathrm{Kg} /$ tree $)$ which resulted from control treatment, in the first and second seasons, respectively. The other treatments recorded in between yield $(\mathrm{Kg} /$ tree $)$ values.

TABLE 2. Effect of spraying $\mathrm{GA}_{3}$ alone or combined with two antioxidants on tree yield for plum fruits during 2011 and 2012 seasons.

\begin{tabular}{|c|c|c|c|c|c|c|c|c|}
\hline \multirow{3}{*}{ Treatments } & \multicolumn{4}{|c|}{ Number of fruits/tree } & \multicolumn{4}{|c|}{ Yield (Kg/tree) } \\
\hline & \multicolumn{2}{|c|}{ Hollywood } & \multicolumn{2}{|c|}{ Golden Japanese } & \multicolumn{2}{|c|}{ Hollywood } & \multicolumn{2}{|c|}{ Golden Japanese } \\
\hline & 2011 & 2012 & 2011 & 2012 & 2011 & 2012 & 2011 & 2012 \\
\hline Control & $400 b^{*}$ & $475 \mathrm{c}$ & $802 \mathrm{~b}$ & $648 \mathrm{a}$ & $13.87 \mathrm{~b}$ & $16.00 \mathrm{c}$ & $25.70 \mathrm{c}$ & $19.41 \mathrm{c}$ \\
\hline $\mathrm{GA}_{3}$ at $25 \mathrm{ppm}$ & $402 \mathrm{~b}$ & $568 \mathrm{~b}$ & 939 a & $548 \mathrm{~b}$ & $14.89 \mathrm{~b}$ & $20.10 \mathrm{~b}$ & $34.89 \mathrm{~b}$ & $21.24 \mathrm{~b}$ \\
\hline $\mathrm{GA}_{3}$ at $50 \mathrm{ppm}$ & $500 \mathrm{a}$ & $622 \mathrm{a}$ & $893 \mathrm{~b}$ & $594 \mathrm{~b}$ & $17.29 \mathrm{a}$ & $24.18 \mathrm{a}$ & $35.90 \mathrm{a}$ & $22.58 \mathrm{~b}$ \\
\hline Citric acid at $50 \mathrm{ppm}$ & $458 \mathrm{a}$ & $510 \mathrm{~b}$ & $800 \mathrm{~b}$ & $570 \mathrm{~b}$ & $18.10 \mathrm{a}$ & $18.72 \mathrm{~b}$ & $28.74 \mathrm{~b}$ & $20.34 \mathrm{~b}$ \\
\hline Vitamin C (ascorbic acid) at $50 \mathrm{ppm}$ & $484 \mathrm{a}$ & $486 \mathrm{c}$ & $779 \mathrm{~b}$ & $502 \mathrm{c}$ & $18.35 \mathrm{a}$ & $17.65 \mathrm{~b}$ & $28.49 \mathrm{~b}$ & $22.50 \mathrm{~b}$ \\
\hline $\mathrm{GA}_{3}$ at $50 \mathrm{ppm}+$ Citric acid at $50 \mathrm{ppm}$ & $508 \mathrm{a}$ & $510 \mathrm{~b}$ & $1000 \mathrm{a}$ & $550 \mathrm{~b}$ & $19.96 \mathrm{a}$ & $19.20 \mathrm{~b}$ & $36.98 \mathrm{a}$ & $24.42 \mathrm{a}$ \\
\hline $\mathrm{GA}_{3}$ at $50 \mathrm{ppm}+\mathrm{Vitamin} \mathrm{C}$ at $50 \mathrm{ppm}$ & $470 \mathrm{a}$ & $539 \mathrm{~b}$ & 957 a & $497 \mathrm{c}$ & $18.20 \mathrm{a}$ & $19.79 \mathrm{~b}$ & $39.63 \mathrm{a}$ & $25.46 \mathrm{a}$ \\
\hline
\end{tabular}

*Values having the same letter(s) within the same column are not statistically significant using new L.S.D. at $5 \%$.

The current results were in harmony with those obtained by Blumenfeld (1981) using gibberellic acid at 15-30 ppm at full bloom on persimmon; and those reported by Abd El-Megeed et al. (2007) who used $\mathrm{GA}_{3}$ and boron on "Canino" apricot and with those of Canli and Orhan, (2009) applying gibberellic acid on sweet cherry. As for antioxidants effects, the present results were in line with the results of Farag (1996) on grapevine, the results revealed on "Anna" apple by spraying citric acid at $0.1 \%$ at three times at growth start, just after fruit set and at 21 days later (Ahmed and Abd El-All, 2007) and the previous results of Mohamed (2008) who found that spraying "Kelsey" plum trees by some antioxidants increased yield and improved fruit quality as compared with the untreated trees. Also, the present results agree with those of Wally et al. (2012) who studied the effect of gibberellic acid and two antioxidants (citric and ascorbic acids) on yield and fruit quality of "Canino" apricot trees. Moreover, Sakr et al. (2013) on soybean plant and Khafagy et al. (2013) on hibiscus. 


\section{Fruit physical characteristics}

Fruit weight, volume and dimensions

The effects of gibberellic acid at 25 and $50 \mathrm{ppm}$ alone or combined with citric and ascorbic acids at $50 \mathrm{ppm}$ on fruit weight, volume and dimensions of "Hollywood" and "Golden Japanese" plum cultivars are presented in Table 3. All treatments increased significantly fruit weight $(\mathrm{g})$, volume $\left(\mathrm{cm}^{3}\right)$ and fruit dimensions (length and diameter $(\mathrm{cm})$ as compared with the control (untreated trees). The most effective treatment on increments of fruit weight, volume and dimensions of fruit for both cultivars; "Hollywood" and "Golden Japanese" plum was spraying gibberellic acid at $50 \mathrm{ppm}$ combined with citric or ascorbic acid at $50 \mathrm{ppm}$ followed by the treatments of using gibberellic acid alone.

As regard to gibberellic acid effects on fruit weight, volumes and dimensions, the obtained results were in agreement with those obtained by Abd El-Megeed et al. (2007) using gibberellic acid and boron on "Canino" apricot and with those reported by Canli \& Orhan (2009) of applying gibberellic acid on sweet cherry. However, $\mathrm{GA}_{3}$ application may stimulate cell expansion and thus increase fruit weight (Zilkah et al., 1997). Zhiguo et al. (1999) stated that $\mathrm{GA}_{3}$ application can delay fruit maturation on the tree, increase fruit weight and prolong the marketing season by four weeks. As for antioxidants effects, the present results were in line with the results obtained on "Anna" apple fruit physical and chemical characteristics which were improved by spraying citric acid at $0.1 \%$ at three times: at growth start, just after fruit set and at 21 days later (Ahmed \& Abd El-All, 2007) and the previous results of Mohamed (2008) who found that spraying "Kelsey" plum trees by some antioxidants (tryptophan, ascorbic acid and vitamin E) increased yield and improved fruit quality as compared with the untreated trees. Conklin (2001) stated that ascorbic acid was involved in plant cell division where its level is high in meristematic tissues and low in zones with little active cell division. Moreover, the present results were in harmony with those of Wally et al. (2012) who studied the effect of gibberellic acid and two antioxidants (citric and ascorbic acids) on yield and fruit quality of "Canino" apricot trees.

\section{Fruit firmness}

Fruit firmness (lb/Inch ${ }^{2}$ ) of "Hollywood" and "Golden Japanese" plum cultivars as affected by spraying gibberellic acid at 25 and $50 \mathrm{ppm}$ alone or combined with citric acid and ascorbic acid at $50 \mathrm{ppm}$ are presented in Table 4. Some sprayed gibberellic acid treatments and two antioxidants treatments increased fruit firmness $\left(\mathrm{Lb} / \mathrm{Inch}^{2}\right)$ compared to unsprayed treatment (control) for the two studied cultivars in both studied seasons.

However, Facteau (1982) found a positive effect of $\mathrm{GA}_{3}$ on pectin fractions in fruits where $\mathrm{GA}_{3}$ may increase flesh firmness or delay fruit softness by some mechanisms involving less methylation of pectins which would leave more sites for $\mathrm{Ca}$ binding. Also, the present results were in agreement with the previous results of Mohamed (2008) who found that spraying "Kelsey" plum trees by some antioxidants (Tryptophan, ascorbic acid and vitamin E) increased yield and improved fruit quality as compared with the untreated trees. Moreover, the

Egypt. J. Hort. Vol. 40, No.1 (2013) 
present results were in harmony with those of Wally et al. (2012) who studied the effect of gibberellic acid and two antioxidants (citric and ascorbic acids) on yield and fruit quality of "Canino" apricot trees.

\section{Chemical Characteristics}

\section{Total Soluble Solids}

Results in Table 4 indicate the effects of gibberellic acid at 25 and $50 \mathrm{ppm}$ alone or combined with citric acid and ascorbic acid at $50 \mathrm{ppm}$ on TSS (\%) of "Hollywood" and "Golden Japanese" plum fruit cultivars. There were no significant differences between all treatments and the control.

\section{Acidity}

Fruit juice acidity percentages of "Hollywood" and "Golden Japanese" plum fruit cultivars as affected by gibberellic acid at 25 and $50 \mathrm{ppm}$ alone or combined with citric acid and ascorbic acid at $50 \mathrm{ppm}$ were presented in Table 4. All treatments decreased fruit juice acidity (\%) without significant differences compared to the control $(0.76$ and $0.89 \%)$ for "Hollywood" as well as (1.07 and $1.10 \%$ ) for "Golden Japanese" cultivars. However, $\mathrm{GA}_{3}$ at $50 \mathrm{ppm}$ in 2011 season $(0.56 \%)$ as well as vitamin C (0.80 and $0.85 \%)$ in 2011 and 2012 seasons decreased acidity significantly.

\section{TSS/acid ratio}

Results in Table 4 reveal the effects of spraying gibberellic acid at 25 and 50 ppm alone or combined with citric acid and ascorbic acid at $50 \mathrm{ppm}$ on TSS/ acid ratio of "Hollywood" and "Golden Japanese" plum fruit cultivars. All sprayed treatments increased significantly fruit TSS/acid ratio of fruits of the two cultivars as compared with the unsprayed treatment (control) during the two studied seasons $(15.79,15.80,9.91$ and 9.09). The most effective treatment on TSS/acid ratio was the spraying of gibberellic acid at $50 \mathrm{ppm}$ on "Hollywood" cv. (18.46 and 16.62) as well as vitamin C "Golden Japanese" (13.38 and 12.12) as compared with the lowest values of the control in the two studied seasons on the two cultivars.

The presented results were in harmony with those obtained by Blumenfeld (1981) using gibberellic acid at 15-30 ppm at full bloom on persimmon; and those reported by Abd-El-Megeed et al. (2007) who used $\mathrm{GA}_{3}$ and boron on "Canino" apricot and with those indicated by Canli and Orhan (2009) applying gibberellic acid on sweet cherry. As for antioxidants effects, the present results were in line of the results of Farag (1996) on grapevine, the results revealed on "Anna" apple by spraying citric acid at $0.1 \%$ at three times: at growth start, just after fruit set and at 21 days later (Ahmed and Abd El-All, 2007) and the previous results of Mohamed (2008) who found that spraying "Kelsey" plum trees by some antioxidants (Tryptophan, ascorbic acid and vitamin E) increased yield and improved fruit quality compared to control. Also, the present results were in agreement with those of Wally et al. (2012) who studied the effect of gibberellic acid and two antioxidants (citric and ascorbic acids) on yield and fruit quality of "Canino" apricot trees. 


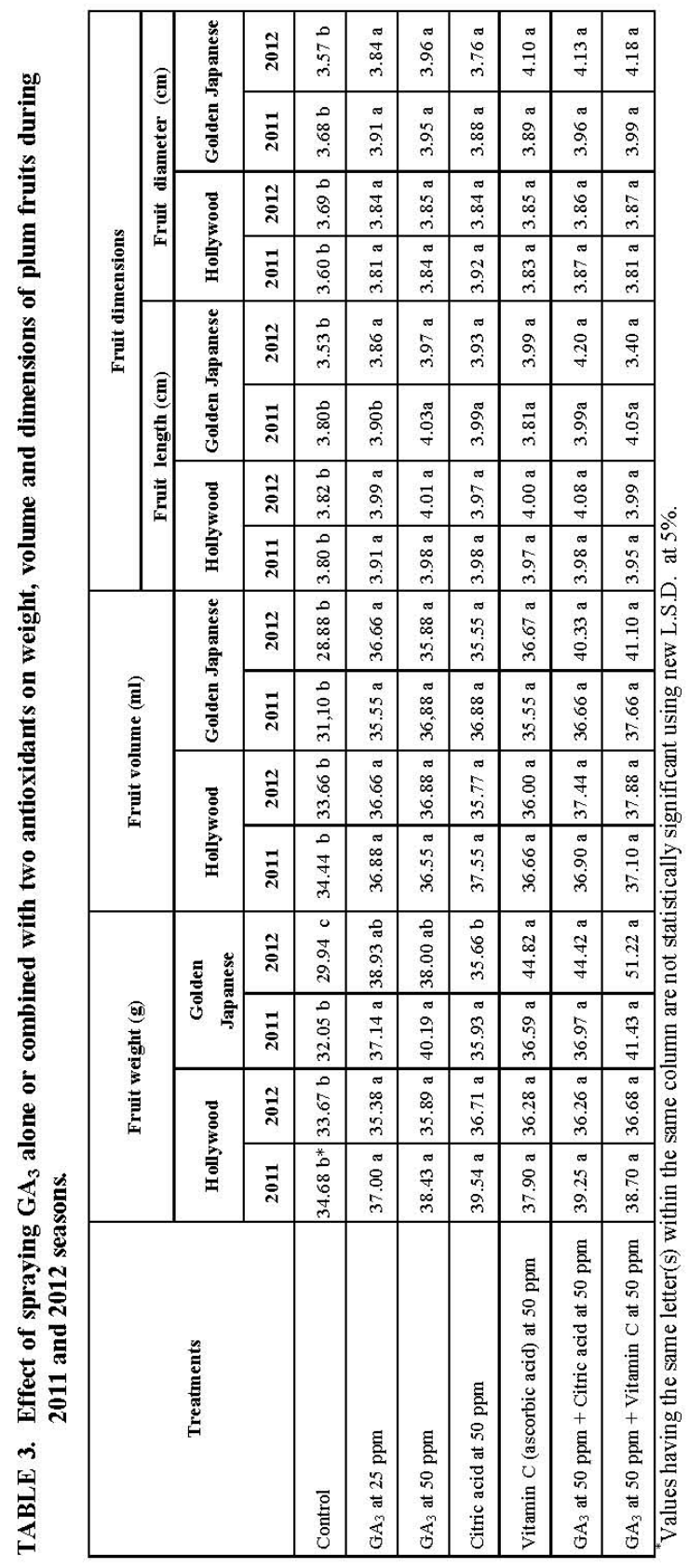

Egypt. J. Hort. Vol. 40, No.1 (2013) 


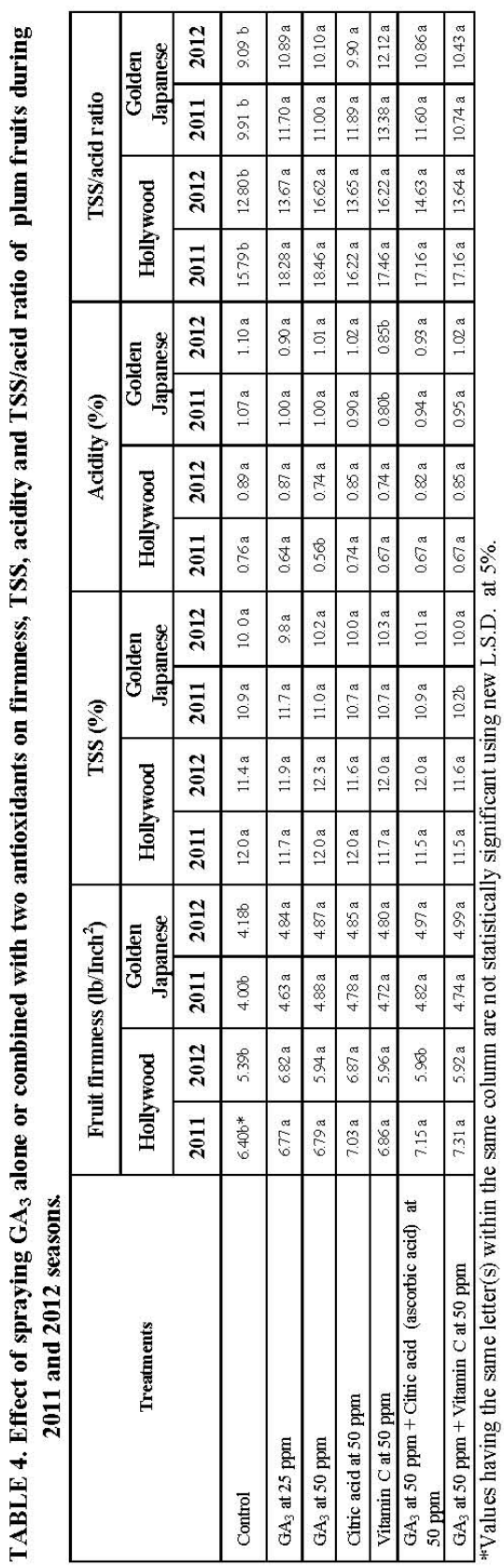

Egypt. J. Hort. Vol. 40, No.1 (2013) 


\section{Conclusion}

It can be concluded that, the best treatment to increase fruit set, yield and improve fruit quality of "Hollywood" and "Golden Japanese" plum cultivars can be obtained by spraying $50 \mathrm{ppm}$ of gibberellic acid mixed by $50 \mathrm{ppm}$ of citric or ascorbic acid twice (at full bloom and two weeks later).

Table (3): Effect of spraying $\mathrm{GA}_{3}$ alone or combined with two antioxidants on weight, volume and dimensions of plum fruits during 2011 and 2012 seasons.

\section{Reference}

Association of Official Agricultural Chemists (A.O.A.C.) (1990) Official Methods of Analysis. Benjanin Franklin Station, Washington D.C., USA pp. 495-510.

Abd El-Mageed Nagwa A. Malka S. Naeima and Wally, A.S.M. (2007) Effect of gibberellic acid and boron spraying on yield and fruit quality of "Canino" apricot trees grown in calcareous new reclaimed soils. The $1^{\text {st }}$ international Conference on desert cultivation. Future of desert cultivation problems \& solutions. 27-29 March, Minia Univ. pp $317-326$.

Addicott, F.T. and Addicott, A.B. (1982) Abscission. Un. Ca. Press. Ltd. London, England. pp. 130-135.

Ahmed, F.F. and Abd El-All, A.M.K. (2007) Influence of spraying seaweed extract and citric acid on yield and fruit quality of "Anna" apple trees. $1^{\text {st }}$ Inter. Conf. Desert Cultivation Problems and Solutions, Minia Univ. 27-29 March: pp. 253-261.

Awad, R.U.A. (2006) Effect of some natural preharvest treatments on mineral content, yield, fruit quality and storability of mango fruits. Ph.D. Thesis, Fac. Agric., Alex. Univ. p. 111.

Blumenfeld, F.A. (1981) Increasing persimmon yields with gibberellic acid. Acta Hort. (ISHS) 120, 237-239.

Canli, A. and Orhan, H. (2009) Effects of Preharvest Gibberellic Acid Applications F on Fruit Quality of '0900 Ziraat' Sweet Cherry. Hort Technology, 19, 5-229.

Chitu, V., Chitu, E. and Braniste, N. (2007) Effect of $\mathrm{GA}_{3}$ and paclobutrzol treatments on fruit set and yield of :"Beurre Bosce" and "Triumf" pears cultivars. Acta Hort., 800, 452-465.

Conklin, P.L. (2001) Recent advances in the role and biosynthesis of Ascorbic acid in plants. Plant, Cell and Environment, 24, 383-394.

Elad, Y. (1992) The use of antioxidants to control gray mould (Botrytic cinera) and white mould (Sclerotinia Sclerotiorum) in various crops. Plant Pathol., 141, 417-426.

El-Sheikh, A.R., Bahan, M.K. and Hamza, A.Y. (1999) The effect of girdling and some growth regulators in fruit drop of persimmon. Acta Agriculturea Universities Jiangxieeusis, 2004 (rd26) No. 5, 754-758.

Egypt. J. Hort. Vol. 40, No.1 (2013) 
Facteau, T.J. (1982) Levels of pectic substances and calcium in gibberellic acid treated Sweet cherry fruit. J. Amer. Soc, Hort. Sci., 107(1),148-151.

Farag, K.M. (1996) Use of urea, phenylalanine, thiamine or their combination to accelerate anthocyanin development and their effect on the storage life of flame seedless grapes. The first Egyptian Hungarian Hort. Conf. Kafr EL-Sheikh, Egypt. 1517 Sept.

Khafagy, M.A., Abd alla, M.Y.A. Hussein, H.A.A. and Sara Ahmed, A.M. (2013) Response of Hibiscus rosa-Sinensis L. to the interactive effect of Seawater salinity and Ascorbic acid. J. Plant Production, Mansoura Univ., 4(1), 51-78.

Magness, J.R. and Taylor, C.F. (1925) An improved type of pressure for the determination of fruit maturity. U.S. Dept. Agric., pp. 350-358.

Ministry of Agriculture Statistics, (2010) Central Management of Horticulture., Egypt.

Mohamed, H.M.A. (2008) Response of "Kelsey" plum trees to application of some antioxidants. M. Sci. Fac. Agric., Minia University.

Sakr, M.T., Heba M. Abd El-Salam, Marouah I. Atta and M.A.A. Abd El-Aal (2013) Alleviating the harmful effect of salinity stress on Soybean plants by using some promoters. J. Plant Production, Mansoura Univ., 4(2), 205-218.

Soliman, A. F., Saad-Alla, M. A. and El-Nokrashi M. A. (1985) Effect of foliar sprays of some nutrients, $\mathrm{GA}_{3}$ and 2,4-D on "Valencia" orange trees. Agric. Res. Review, 63 (3), 35-48.

Steel, R.G.D. and Torrie, T.H. (1980) Principles and Procedures of Statistics. $2^{\text {nd }}$ ed. McGraw Hill, N.Y. USA.

Wally, A.S., Nagwa, A. Abd El-Megeed and Fattma Abou-Grah (2012) Effect of gibberellic acid and two antioxidants on yield and fruit quality of "Canino" apricot trees. Minia International Conference for Agriculture and Irrigation in the Nile Basin Countries, 26 -29 March 2012, El-Minia, Egypt.

Zhiguo, J., Yousheng, D. and Zhiqiang, J. (1999) Combinations of $\mathrm{GA}_{3}$ and AVG delay fruit maturation, increase fruit size and improve storage life of 'Feicheng' peaches. $J$. Hort. Sci. and Biotech, 74(5), 579-583.

Zilkah, S., Lurie, S., Lapsker, Z., Zuthi, Y., David, G., Yesselson, Y., Antman, S. and Ben Aric, R. (1997) The ripening and storage quality of nectarine fruits in response preharvest application of gibberellic acid. J. Hort. Sci., 72, 355-362.

(Received 26/3/2013; accepted 14/5/2013) 


\section{تأثثير حمض الجبريليك منفرداً أو مخلوطاً مـع إثنين من مضـادات

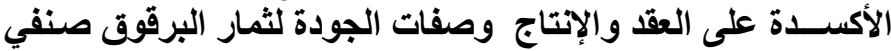 "هوليود" و"ياباني ذهبى والانتي وم"}

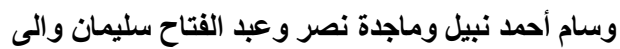

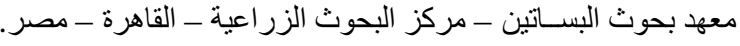

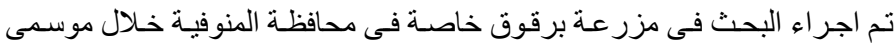

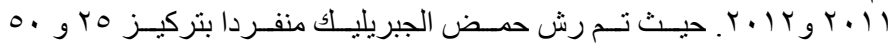

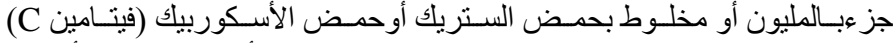

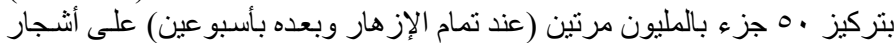

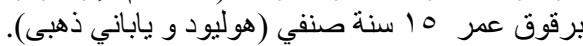

وقد أدت كل المعاملات إلى زيادة معنوية فى عقد الثمـار (\%) وكميـة الإنتاج

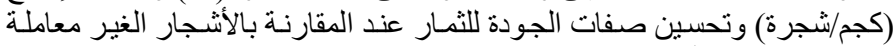

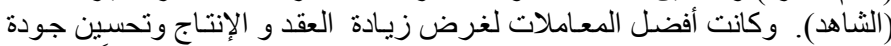

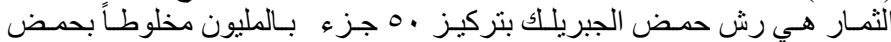

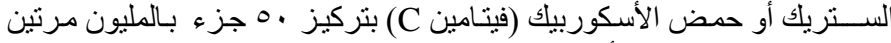

(عند تمام الإز هار وبعده بأسبو عين).

Egypt. J. Hort. Vol. 40, No.1 (2013) 